\title{
The Urban Climate of Tokyo
}

\author{
Shuji Yamashita
}

\begin{abstract}
This paper describes the urban climate in Tokyo phenomenally from the viewpoint of regional geography. Climatic elements discussed here are temperature, precipitation, humidity and solar radiation. There are previous studies, written in English, such as those by YosHINo (1981), KawAMURA (1985) and YAMASHITA (1988), and so this paper is generally intended to deal with others than those noted in the above-mentioned three papers.

Secular changes of seasonal variations of air temperature are shown at first. Next, Tokyo's heat island intensity is shown diurnally and seasonally as an isopleth. Using Fuchu and Koshigaya as the rural control sites for Tokyo, heat island intensity and its diurnal frequency distribution are obtained by the temperature differences with Tokyo. Its behavior is also explained by the difference of wind direction and speed.

Annual variation of precipitation is shown since the beginning of the observation. Moreover, the change of days is shown with ranked precipitation amounts as follows: $0.0 \mathrm{~mm}, 0.1-1.0 \mathrm{~mm}, 1.1-9.9$ $\mathrm{mm}, 10.0 \mathrm{~mm}$ and over. Effects of a city on precipitation are not so simple because the number of convective rain days with $31 \mathrm{~mm}$ and over is very variable dependent on the atmospheric conditions of the period.

Humidity has decreased very drastically for the last two decades. Reduction index of insolation in Tokyo is shown as monthly variations, and this is a very good indicator for total air pollution. Judging from tendency of this indicator, air pollution condition in Tokyo is not always improved in these days.
\end{abstract}

Key words: urban climate, heat island, heat island intensity, reduction index, DID

\section{INTRODUCTION}

The so-called city of Tokyo, consisting of 23 wards, has a population of 8.4 million in an urban area of $590 \mathrm{~km}^{2}$ according to the census in 1985. The population of the Metropolitan area including Yokohama, Chiba and Kawasaki cities amounts to 23 million within the sphere of $40 \mathrm{~km}$. Such a concentration of population is a result of urbanization, and leads to significant modification of the physical environment of the urban areas. The purpose of this paper is to describe the urban climate of Tokyo and its surrounding areas from the viewpoint of regional geography with special emphasis on the urban climatic phenomena. However, there are previous studies, written in English, such as Yoshino (1981), KAWAMURA (1985) and YaMASHITA (1988), and here discussion is mainly based on others than those noted in the above-mentioned.

Many cities in Japan were affected by World War II which resulted in almost complete destruction of their urban areas. In this regard, Tokyo was not an exception and indeed, was one of the most severely affected cities among them. Consequently, annual variations of many climatic elements had shown discontinuous changes around 1944-1945. Thereafter the economy was gradually recovering, so that by the 1960's it entered a period of remarkable development. The Metropolitan Tokyo Area, especially the Keihin (Tokyo-Kawasaki-Yokohama) industrial area, played the most important role. By the second half of the 1960's, the Keiyo (Tokyo-ChibaKisarazu) industrial area also contributed to the Japanese economic expansion. Fig. 1 shows the expansion of the Metropolitan Tokyo Area ex-

*Department of Geography, Tokyo Gakugei University, Koganei-shi, Tokyo 184 


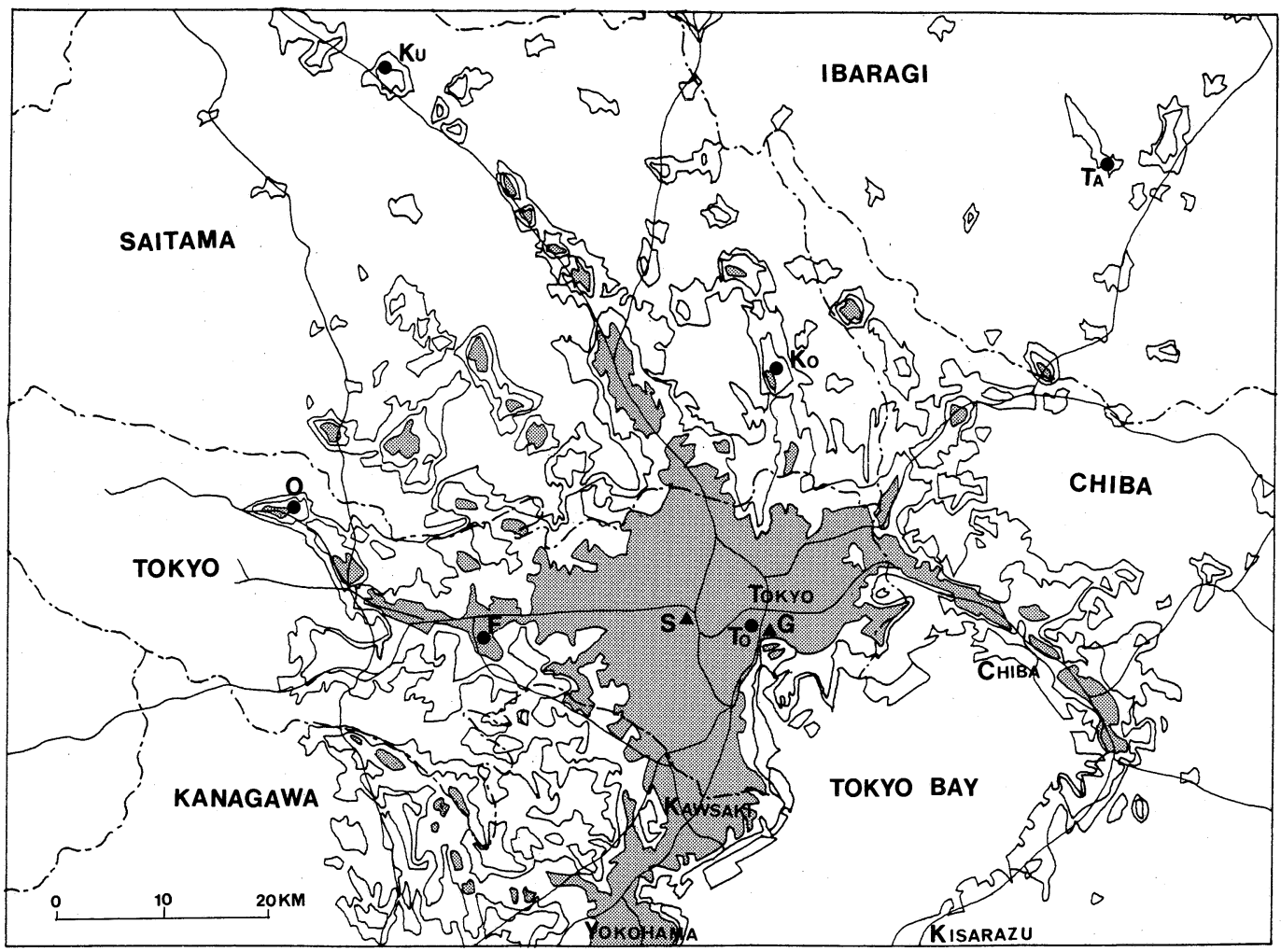

Figure 1. Development of the Tokyo Metropolitan Area and locations of the stations used in this study The inner line of the Tokyo Metropolitan Area is DID in 1960, the middle in 1970 and the outer in 1985. To: Tokyo, Ku: Kumagaya, Ko: Koshigaya, Fu: Fuchu, O: Ome, Ta: Tateno, S: Nishi-Shinjuku, G: Ginza, -: Japan Railway lines, --_: boundary of prefectures

pressed with DID (Densely Inhabited District) population. As a result, the physical environment of the Metropolitan Tokyo Area became more urbanized, that is, modified more climatically, hydrologically, geomorphologically and biologically. Urban climate is one of the most typical examples of environments which man has inadvertently produced.

\section{TEMPERATURE}

It is well known in general that an urban area is warmer than a surrounding rural area, and this difference in air temperature is called the urban temperature excess. The distribution map of air temperature in urban and surrounding areas resembles an island shown on a topographical map, and so it has been called a heat island for its similarity. Also, this difference in air temperature between an urban and a rural area is de- fined as heat island intensity. In this paper, secular change of air temperature, daily variation of heat island intensity and soil temperature will be described.

\section{Secular change of air temperature}

Fig. 2 shows secular change of air temperature by season from 1901 to 1986 in Tokyo. Winter (the first chart in Fig. 2) means the average of the values for December, January and February. The long-term mean value is $4.9^{\circ} \mathrm{C}$ with values of air temperature below the mean prior to 1950 , and above the mean after 1950. Another feature is that there is a clear tendency of increasing air temperature since 1945 .

Spring is March, April and May, and its mean air temperature is $12.8^{\circ} \mathrm{C}$. The general tendency is almost similar to that of the winter. Namely, temperature had been below the mean until 1950 or so, and thereafter, had been above with a 

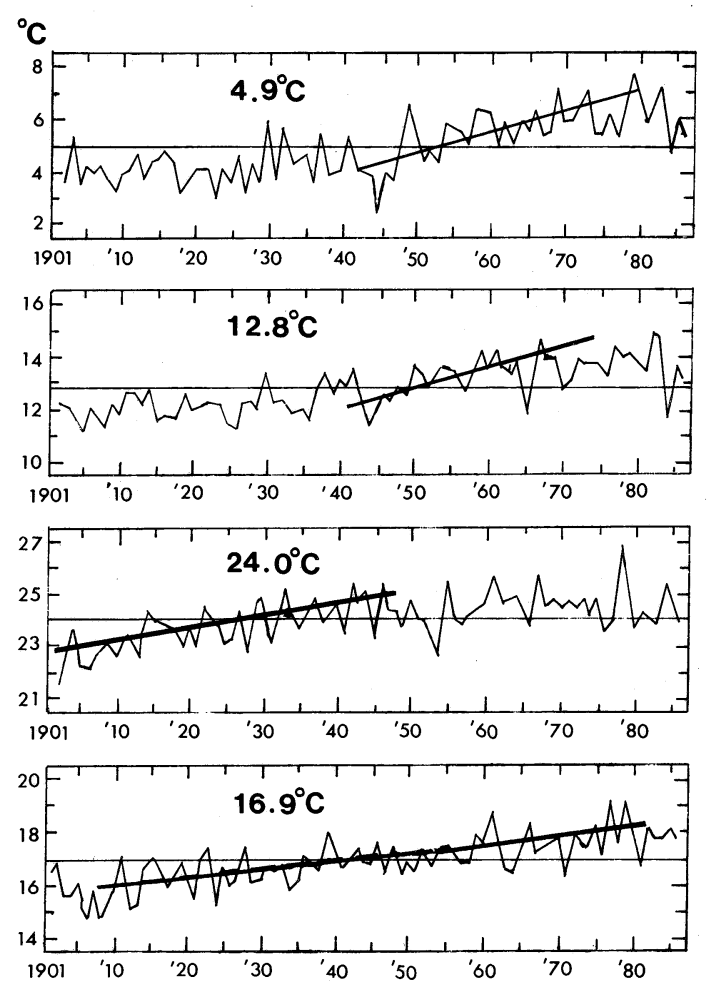

Figure 2. Secular change of air temperature according to seasons in Tokyo

Technical Data Series of Japan Metrorological Agency, No. 53. Trend lines weredrawn by $\mathrm{Y}_{\text {AMASHITA. }}$

generally increasing tendency until 1980. Subsequently, a decrease has been apparent. According to the overall feature of the regression line, the increasing tendency occurred from around 1940 to around 1970.

Summer (June, July and August) is somewhat different from the case of winter or spring. Air temperature was below the mean until around 1930, and thereafter generally above except for a few years in the early to mid-fifties. After 1960, it is almost always above the mean. As a whole, there is a distinct tendency of temperature increasing from 1901 to 1945 , and afterwards, above the mean value of $24.0^{\circ} \mathrm{C}$ has been maintained with no apparent trend in temporal variation.

In case of autumn, values are averaged for September, October and November, and its tendency is almost the same as the case of winter and spring. Between 1901 and the mid-thirties, air temperature was below the mean, and after that stayed around the mean value of $16.9^{\circ} \mathrm{C}$ until around 1958. Thereafter, it became higher than the mean value and increased until 1980. As a whole, it showed a tendency of constant increasing from 1905 to about 1980.

\section{Daily variation of heat island intensity}

Heat island intensity in Tokyo was at first defined as the difference in air temperature between Tokyo (sea level height $6 \mathrm{~m}$ ) and Kumagaya (s.l.h. $30 \mathrm{~m}$ ) which is a local city located about $60 \mathrm{~km}$ north-northwest of Tokyo. Data used here is the mean value averaged over 15 years from 1964 to 1978. As shown in Fig. 3, heat island intensity is large at night during winter, and its maximum value amounts to more than $3.0^{\circ} \mathrm{C}$. On the other hand, it is negative at day during summer. This is due to the daytime heating in Kumagaya and sea breeze effects in Tokyo. Namely, temperature in Kumagaya is influenced by basin efects due to its inland location, whereas along the Tokyo bay area, sea breeze occurs in general when the gradient of atmospheric pressure is weak, and thereby affects temperature rise in Tokyo.

Essentially, heat island intensity is very difficult to define because of difficulty or uncertainty in

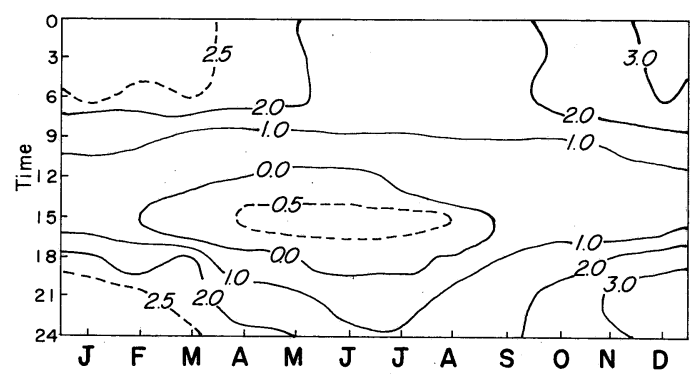

Figure 3. Diurnal Variation of temperature difference between Tokyo and Kumagaya.

defining rural area. In general, the rural-urban boundaries are often not distinct at all. The Tokyo Metropolitan Area is particularly obscure in its boundaries because Tokyo is continually expanding as the sprawl phenomenon (see Fig. 1), and it is no exaggeration to say that the whole area of the Kanto Plain, where Tokyo is located in its southern part, is more or less urbanized. Also, there is no large surrounding greenbelt as 
in London, England. Thus, the distinct cliff of the heat island noted by OKE (1978) is not observed in Tokyo, but rather, air temperatures gradually change from the urban center to the surrounding rural areas. As a result, the heat island intensity in Tokyo is highly dependent on the rural and urban station used. Representativeness of the rural station is thus important, and the station needs to be well-defined as that of the urban site. Fig. 4 shows isopleth of heat island intensity using Ome (s.l.h. $135 \mathrm{~m}$ ), located about $40 \mathrm{~km}$ west of Tokyo, as the rural site. Data used here are mean values averaged over six years from 1978 to 1983 . In this figure, the heat island appears all the time, both diurnally and seasonally. In particular, maximum heat island intensity amounts to more than $5^{\circ} \mathrm{C}$ in late December and

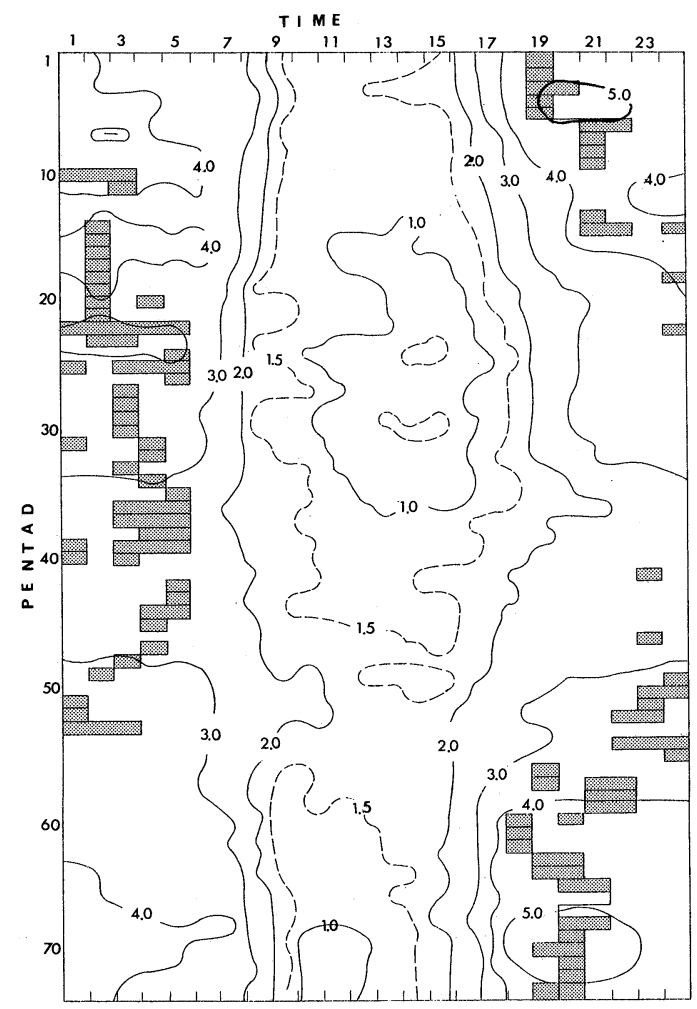

Figure 4. Isopleth of heat island intensity averaged from 1978 to 1983 using Ome as the rural site.

The shaded parts show maximum value of daily heat island intensity, and each pentad is as follows; 1: Jan. 1-5, 10: Feb. 15-19, 20: Apr. 6-10, 30: My 26-31, 40: Jul. 15-19, 50: Sep. 3-7, 60: Oct. 23-27, 70: Dec. $12-16$
mid-January in the late evening from 19:00 to 20:00. The interesting feature is the seasonal change in the occurrence time of maximum heat island intensity. As shown in Fig. 4 minimum heat island intensity occurs midnight to early morning from early spring to summer, and late evening from autumn to winter. This difference may be explained by the heating or cooling season, but further study should be needed. With Ome assumed to be esentially a rural environment of Tokyo, heat island intensity remains always positive. Its minimum value appears only for a very short time from 13:00 to 15:00 during mid-April and late May, and reaches $0.4^{\circ} \mathrm{C}$ - Heat island intensity less than $1.0^{\circ} \mathrm{C}$ occurs during the daytime from late February to early June, and partly in December. However, it should be noted that these daytime values can be occurred only by the sea level difference of both stations. Daily amplitude of heat island intensity is minimum from June to July, and become maximum from December to January.

In order to examine the behavior of heat island in Tokyo, Koshigaya and Fuchu meteorological stations were selected for rural areas. Koshigaya is located $23 \mathrm{~km}$ due north and Fuchu is $26 \mathrm{~km}$ due west of the Tokyo meteorological station. Both are local cities with less than 200,000 of DID population. Therefore, both stations are influenced by the urban atmosphere of Metropolitan Tokyo according to the wind direction and speed. In cases of south and west winds, heat island intensity with Fuchu $\left(\Delta \mathrm{T}_{\mathrm{F}}\right)$ was larger than that with Koshigaya $\left(\Delta \mathrm{T}_{\mathrm{K}}\right)$, and in case of north and east winds, it was vice versa, namely, $\Delta \mathrm{T}_{\mathrm{K}}$ was larger. Fig. 5 shows the frequency distribution of heat island intensity in February of 1981 and 1982 obtained using the above rural stations. During the daytime, the histograms are rather synmetrical centered on zero. This synmetrical feature can be explained by south or east winds. During the nighttime, almost all intensities are positive, and heat island intensities are slightly prevalent with Fuchu than with Koshigaya station.

\section{Soil temperature}

Although heat island is generally regarded as a phenomenon associated with the horizontal distribution of air temperature, a similar phenome- 

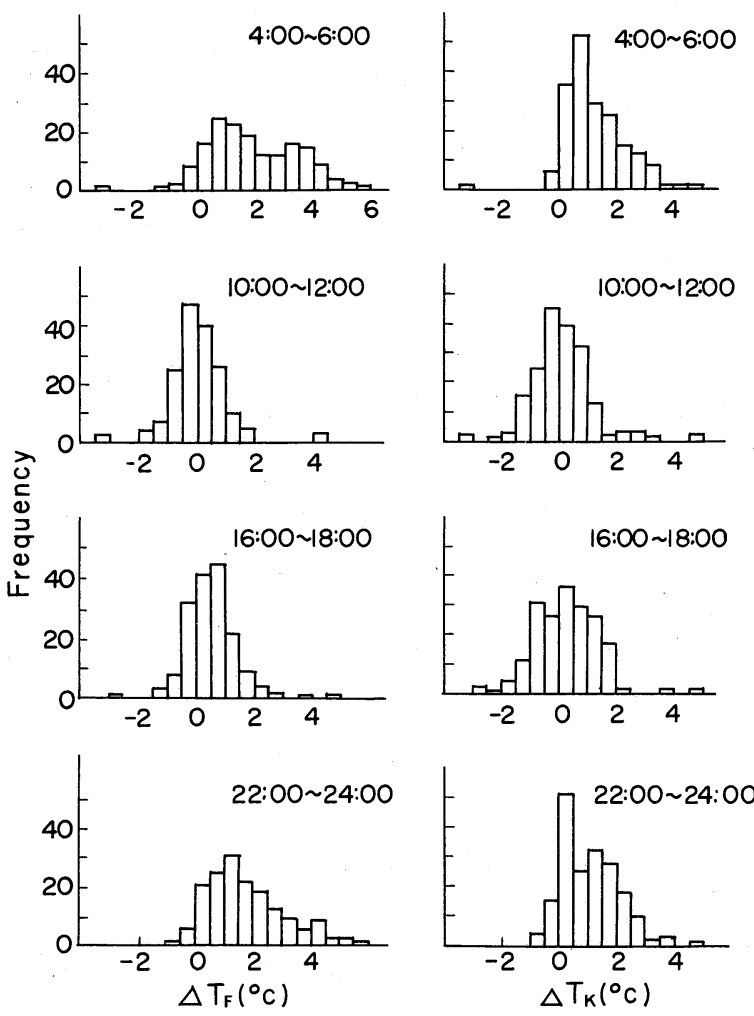

Figure 5. Frequency distribution of Tokyo's heat island intensity with Fuchu as the rural control site $\left(\Delta \mathrm{T}_{\mathrm{F}}\right)$ and Koshigaya as the rural control site $\left(\Delta \mathrm{T}_{\mathrm{K}}\right)$.

non can also be found using soil temperature distribution. This was originally observed by Nishizawa et al. (1977) in central Tokyo. Fig. 6 shows observed soil temperature distribution at a depth of $90 \mathrm{~cm}$ in summer and in winter. Generally speaking, the earth's surface absorbs shortwave radiation from the sun during the day, and emits longwave radiation as a whole. Accordingly the nearby underlying surface layer has a distinct diurnal variation of temperature, whose amplitude becomes smaller with increasing depth. Finally, at a depth of more than 60 $\mathrm{cm}$, soil temperatures remain constant throughout the day. Thus the depth of $90 \mathrm{~cm}$ is deep enough to investigate horizontal distribution of soil temperature by moving observations. As shown in Fig. 6, the heat island appears in the soil temperature distribution during both summer and winter. In particular, the so-called urban center of Tokyo, that is, the

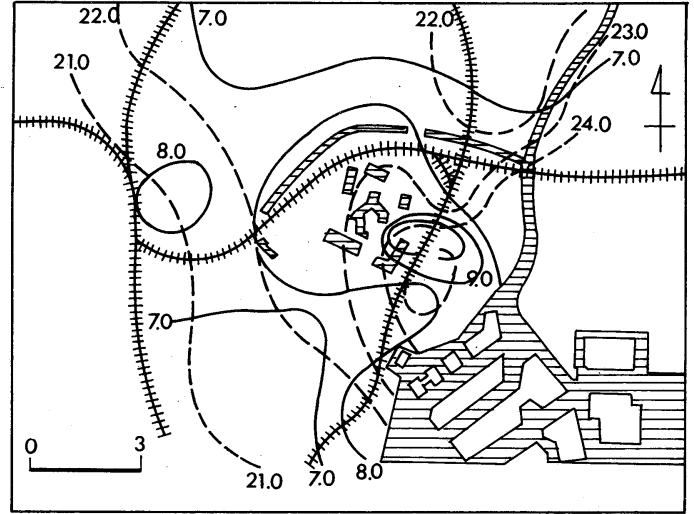

Figure 6. Horizontal distribution of soil temperature in Tokyo at a depth of $90 \mathrm{~cm}$ (NISHIZAWA, 1977)

Solid line is for winter and broken line is for summer

Ginza-Yurakucho-Kasumigaseki area, is characterized by higher soil temperatures. This was explained by the soil moisture difference between the urban center and suburban areas (NisHIZAwA et al., 1977).

\section{PRECIPITATION}

Urban effects on precipitation are very important judging from one of the two main climatic elements, that is, energy and water. However, it is very difficult to assess because the precipitation phenomena vary in time and space discontinuously. Generally, a city results in precipitation increase due to: (1) more condensation nuclei as a result of air pollution, (2) increased upward air flow due to heat island. However, there are contrary opinion that overabundance of condensation nuclei leads to precipitation decrease. Thus, here it is phenomenally treated according to total amount and frequency of days with rain.

\section{Secular change}

In Japan there are large amounts of rainfall due to typhoons or fronts, therefore it is rather difficult to infer the urban effects on amounts of precipitation. Fig. 7 shows secular change of annual amount of precipitation in Tokyo. Although the tendency is not evident, according to the 5-year running mean there is some trend, more or less. Namely, during 1895-1920 peri- 
od there is an increasing trend, and thereafter untill 1950, significant waves of increasingdecreasing patterns are evident. During the $1950-1960$ period, the oscillations are small and the trend line shows a decreasing tendency.

Small rainfall amounts have a clear tendency in number of days in the case of Tokyo. Table 1 shows the number of days according to rank of precipitation amount. The figures in the table refer to the sum of numbers for each season and annually for ten-year periods, and the rank of precipitation amount is as follows: $0.0 \mathrm{~mm}$ (trace), $0.1-1.0 \mathrm{~mm}, 1.1-9.9 \mathrm{~mm}$, and $10 \mathrm{~mm}$ and over. However, in 1967 the method of precipitation measurement changed, and precipitation of less than $0.5 \mathrm{~mm}$ was supposed to be recorded as $0.0 \mathrm{~mm}$. So the numbers of days with daily precipitation of $0.0-1.0 \mathrm{~mm}$ are shown for the last decade in Table 1. As is evident from the table, the number of $0.0 \mathrm{~mm} /$ day had increased

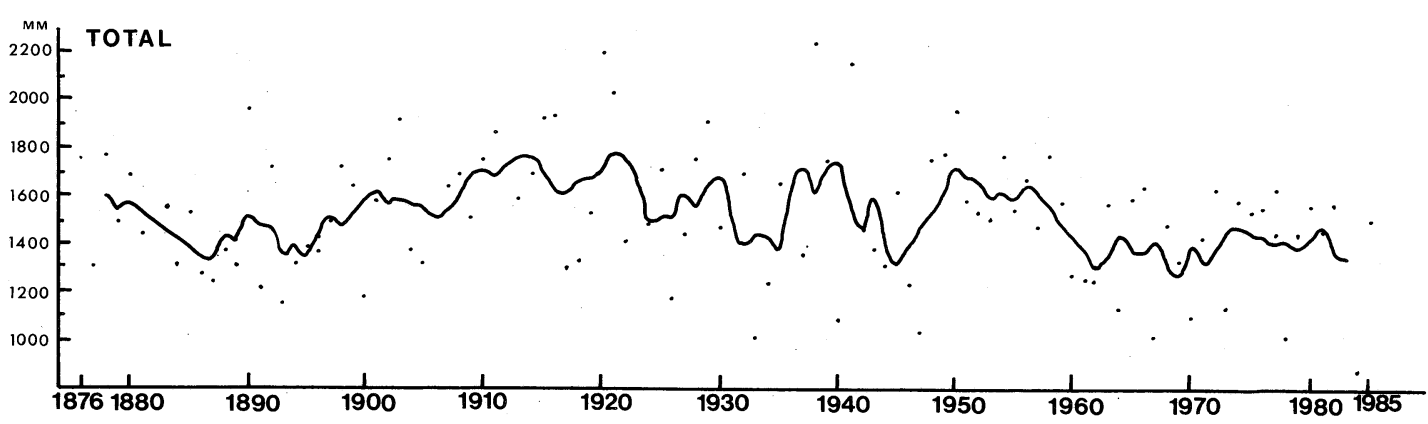

Figure 7. Annual change of total precipitation in Tokyo.

Table 1 Change of number of days with ranked precipitation amounts (1881 1970: YoshINO, 1971 1980: YAMASHITA)

\begin{tabular}{|c|c|c|c|c|c|c|c|c|c|c|c|}
\hline & & $\begin{array}{r}1881 \sim \\
1890\end{array}$ & $\begin{array}{r}1891 \sim \\
1900\end{array}$ & $\begin{array}{r}1901 \sim \\
1910\end{array}$ & $\begin{array}{r}1911 \sim \\
1920\end{array}$ & $\begin{array}{r}1921 \sim \\
1930\end{array}$ & $\begin{array}{r}1931 \sim \\
1940\end{array}$ & $\begin{array}{r}1941 \sim \\
1950\end{array}$ & $\begin{array}{r}1951 \sim \\
1960\end{array}$ & $\begin{array}{r}1961 \sim \\
1970\end{array}$ & $\begin{array}{r}1971 \sim * \\
1980\end{array}$ \\
\hline $\begin{array}{l}\text { Dec } \\
\text { Jan } \\
\text { Feb }\end{array}$ & $\left\{\begin{array}{l}0.0 \mathrm{~mm} \\
0.1 \sim 1.0 \\
1.1 \sim 9.9 \\
10.0\end{array}\right.$ & $\begin{array}{l}48 \\
69 \\
51 \\
50\end{array}$ & $\begin{array}{l}88 \\
63 \\
85 \\
66\end{array}$ & $\begin{array}{r}100 \\
47 \\
93 \\
70\end{array}$ & $\begin{array}{r}76 \\
47 \\
111 \\
71\end{array}$ & $\begin{array}{r}77 \\
56 \\
109 \\
56 \\
\end{array}$ & $\begin{array}{l}77 \\
69 \\
83 \\
72\end{array}$ & $\begin{array}{l}96 \\
72 \\
89 \\
49\end{array}$ & $\begin{array}{r}75 \\
64 \\
108 \\
70\end{array}$ & $\begin{array}{r}111 \\
46 \\
84 \\
52 \\
\end{array}$ & $\begin{array}{l}76 \\
62 \\
\end{array}$ \\
\hline $\begin{array}{l}\text { Mar } \\
\text { Apr } \\
\text { May }\end{array}$ & $\left\{\begin{array}{l}0.0 \mathrm{~mm} \\
0.1 \sim 1.0 \\
1.1 \sim 9.9 \\
10.0\end{array}\right.$ & $\begin{array}{r}38 \\
104 \\
182 \\
138 \\
\end{array}$ & $\begin{array}{r}98 \\
98 \\
180 \\
133 \\
\end{array}$ & $\begin{array}{r}121 \\
84 \\
198 \\
136 \\
\end{array}$ & $\begin{array}{l}103 \\
105 \\
175 \\
123 \\
\end{array}$ & $\begin{array}{r}79 \\
99 \\
171 \\
125 \\
\end{array}$ & $\begin{array}{r}88 \\
107 \\
167 \\
109 \\
\end{array}$ & $\begin{array}{l}111 \\
103 \\
151 \\
123 \\
\end{array}$ & $\begin{array}{l}134 \\
103 \\
161 \\
150 \\
\end{array}$ & $\begin{array}{r}157 \\
89 \\
135 \\
124 \\
\end{array}$ & $\begin{array}{l}237 \\
132 \\
122 \\
\end{array}$ \\
\hline $\begin{array}{l}\text { Jun } \\
\text { Jul } \\
\text { Aug }\end{array}$ & $\left\{\begin{array}{l}0.0 \mathrm{~mm} \\
0.1 \sim 1.0 \\
1.1 \sim 9.9 \\
10.0\end{array}\right.$ & $\begin{array}{r}52 \\
110 \\
168 \\
123 \\
\end{array}$ & $\begin{array}{l}133 \\
124 \\
175 \\
110\end{array}$ & $\begin{array}{l}131 \\
102 \\
216 \\
166\end{array}$ & $\begin{array}{l}116 \\
130 \\
177 \\
140 \\
\end{array}$ & $\begin{array}{l}128 \\
120 \\
161 \\
114\end{array}$ & $\begin{array}{l}145 \\
105 \\
154 \\
113\end{array}$ & $\begin{array}{l}137 \\
115 \\
142 \\
141\end{array}$ & $\begin{array}{l}159 \\
128 \\
182 \\
133\end{array}$ & $\begin{array}{r}209 \\
85 \\
155 \\
127 \\
\end{array}$ & $\begin{array}{l}261 \\
171 \\
121\end{array}$ \\
\hline $\begin{array}{l}\text { Sep } \\
\text { Oct } \\
\text { Nov }\end{array}$ & $\left\{\begin{array}{l}0.0 \mathrm{~mm} \\
0.1 \sim 1.0 \\
1.1 \sim 9.9 \\
10.0\end{array}\right.$ & $\begin{array}{r}58 \\
94 \\
158 \\
132\end{array}$ & $\begin{array}{r}81 \\
107 \\
144 \\
149\end{array}$ & $\begin{array}{l}101 \\
117 \\
162 \\
141\end{array}$ & $\begin{array}{l}110 \\
105 \\
106 \\
160\end{array}$ & $\begin{array}{r}87 \\
89 \\
155 \\
145\end{array}$ & $\begin{array}{r}105 \\
98 \\
158 \\
140\end{array}$ & $\begin{array}{l}136 \\
100 \\
149 \\
133\end{array}$ & $\begin{array}{r}128 \\
91 \\
177 \\
150\end{array}$ & $\begin{array}{r}175 \\
91 \\
126 \\
113\end{array}$ & $\begin{array}{l}230 \\
114 \\
135\end{array}$ \\
\hline Annual & $\left\{\begin{array}{l}0.0 \mathrm{~mm} \\
0.1 \sim 1.0 \\
1.1 \sim 9.9 \\
10.0\end{array}\right.$ & $\begin{array}{l}203 \\
373 \\
605 \\
444\end{array}$ & $\begin{array}{l}390 \\
392 \\
579 \\
458\end{array}$ & $\begin{array}{l}453 \\
349 \\
665 \\
513\end{array}$ & $\begin{array}{l}407 \\
376 \\
629 \\
495\end{array}$ & $\begin{array}{l}366 \\
366 \\
599 \\
439\end{array}$ & $\begin{array}{l}415 \\
382 \\
560 \\
433\end{array}$ & $\begin{array}{l}480 \\
383 \\
532 \\
448\end{array}$ & $\begin{array}{l}497 \\
387 \\
625 \\
502\end{array}$ & $\begin{array}{l}654 \\
312 \\
498 \\
416\end{array}$ & $\begin{array}{r}83 \\
493 \\
440\end{array}$ \\
\hline
\end{tabular}

*The observation method was changed, and precipitation of less than $0.5 \mathrm{~mm}$ was recorded as 0.0 mm. Therefore, the numbers of $0.0-1.0 \mathrm{~mm} / \mathrm{day}$ are shown in this column. 
since the beginning of observation until $1901-1910$ period, however, afterwards it was minimum during the $1921-1930$ period though overall showed an increasing tendency. On the other hand, the frequencies of $0.1-1.0 \mathrm{~mm} /$ day and, $10 \mathrm{~mm} /$ day and over do not vary very much until $1961-1970$ period. The value of $1.1-9.9$ $\mathrm{mm} /$ day has been decreasing except for $1951-1960$ period. The values for each season show almost the same tendency as the secular change of the annual total.

Through all ranks of precipitation amounts, the tendencies have dramatically changed during the last two decades. But this requires more detailed study, because its reason is not known whether it is the change of measurement method or the result of urbanization.

\section{Heavy rainfall}

During the 1970's, the METROMEX (Metropolitan Meteorological Experiment) program provided pioneering researches of urban effects on precipitation, specifically from the aspect of cloud physics. Some important findings included the observation that urban effect appeared most distinctly on convective rain, namely, the number of thunder-storm days during summertime.

In Tokyo, there are some studies of urban effects on precipitation which more or less substantiate such findings. YoNETANI (1981) investigated heavy rainfall greater than $31 \mathrm{~mm}$ in August excluding cases of typhoon and tropical cyclone, and demonstrated the larger frequency during the 1972-1976 period compared with the 1957-1961 period as shown in Fig. 8. However, additional investigation to cover the period ending 1986 has revealed controversial results. For example, during the $1982-1986$ period, the frequencies in the central area of Tokyo were actually low compared with high frequencies of heavy rainfall in nearby rural areas (HOSAKI, 1987).

The period of 1967-1971 (not shown in the figure) corresponds to that of 1977-1981 with respect to atmospheric conditions because the frequency of heavy rainfall was almost equal in both urban and rural areas. This trend may be explained by air pollution conditions, that is, dust fall or so-called black smog during the 1957-1961 period which resulted in an over-
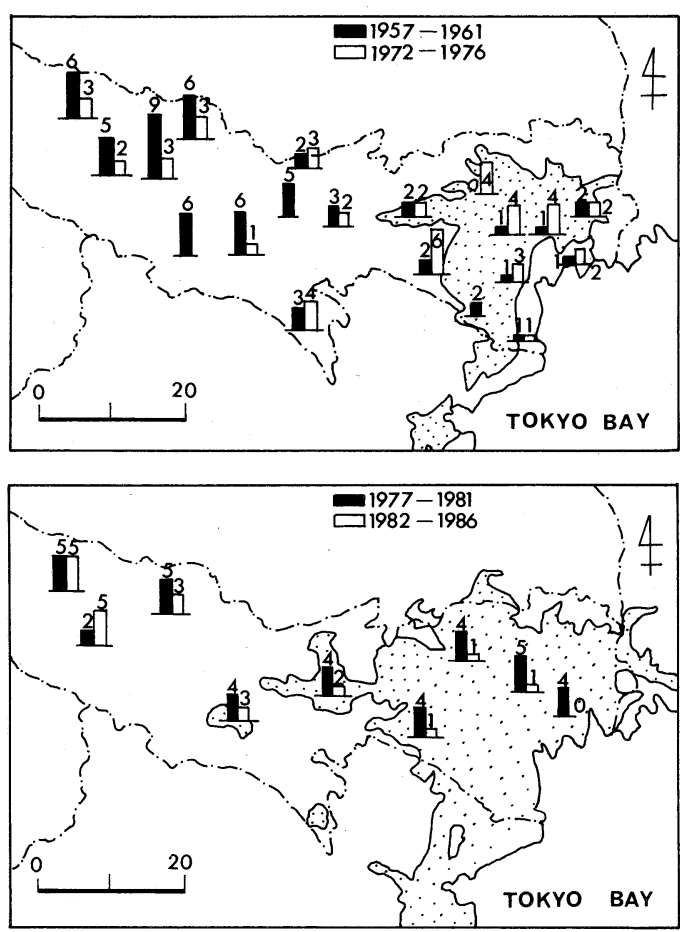

Figure 8. Frequency distribution of heavy rainfall over $31 \mathrm{~mm}$

Dotted area indicates built-up area, upper: YoNETANI, 1982, lower: HoSAKı, 1987

abundance of condensation nuclei in the urban atmosphere. During the $1972-1976$ period, atmospheric conditions had improved due to energy shift to petroleum and as well, due to administrative measures, whereas the 1982 - 1986 period was again back to the condition of the 1957-1961 period judging from frequency of heavy rainfall. However, this was very contradictory because there were many high-rise buildings and increased energy consumptions during this last period which expected more heavy rainfall.

\section{HUMIDITY AND SOLAR RADIATION}

\section{Humdity}

Annual variations of 5-year mean relative humidity are shown in Table 2 for all seasons since 1951. Remarkable decrease occurs in winter, which correspond to the period of temperature rise. The value of relative humidity has fallen about $10 \%$ in winter, about $5 \%$ in spring and 
Table 2. Recent change of relative humidity by season in Tokyo

\begin{tabular}{|c|c|c|c|c|}
\hline & Winter & Spring & Summer & Autumn \\
\hline $1951 \sim 1955$ & $62 \%$ & $69 \%$ & $80 \%$ & $74 \%$ \\
\hline $1956 \sim 1960$ & 58 & 65 & 78 & 75 \\
\hline $1961 \sim 1965$ & 55 & 64 & 76 & 70 \\
\hline $1966 \sim 1970$ & 51 & 61 & 73 & 66 \\
\hline $1971 \sim 1975$ & 52 & 61 & 73 & 65 \\
\hline $1976 \sim 1980$ & 52 & 61 & 74 & 67 \\
\hline $1981 \sim 1985$ & 51 & 64 & 75 & 67 \\
\hline
\end{tabular}

summer, and about $8 \%$ in autumn.

Secular change of 5-year average since 1876 also shows this recent decrease. In the 19th century, relative humidity was around $75 \%$, but in the 20th century, it has been decreasing gradually and amounted to less than $65 \%$ in the 1970's (Yoshino, 1975).

As temperature increases, relative humidity does inevitably become lower. Therefore, secular change of relative humidity reflects partly temperature rise. Омото (1988) separated the effect of temperature increase and absolute water vapor pressure. The effect of water vapor pressure was found to be larger than that of temperature increase during the $1940-1975$ period, and maximum value appeared in late 1960's.

\section{Solar radiation}

Human activities release many kinds of pollutants in the atmosphere which affect solar radiation incident on the horizontal surface. Before 1965 , coal was the primary energy source and resulted in dust pollution. Around 1965, the principal energy source in Japan dramatically shifted from coal to petroleum. As a result, the main atmospheric pollutant became sulphur dioxide instead of dust, and this was called white smog in contrast to the previous black smog.

By the mid-1970's, photo-chemical smog became the first-ranked problem of atmospheric pollution due to rapid increase in automobiles in Japanese society. However, atmospheric pollution in the Tokyo Metropolitan Area has since been improved due to the Atmospheric Protection Law and general efforts of many companies for pollution protection measures.

The improvement of atmospheric pollution mentioned above is judged from the so-called data observed by governmental agencies. At- mospheric pollutants are not always specified only by these data. A good independent indicator for total atmospheric pollution is solar radiation (YAMASHITA, 1973). Solar radiation is also very important because it is the fundamental energy for the earth.

Fig. 9 shows annual variations of monthly reduction index of insolation in Tokyo. This is obtained by calculating the percent reduction from insolation in Tateno which is located $30 \mathrm{~km}$ north of Tokyo. There are distinct decreasing

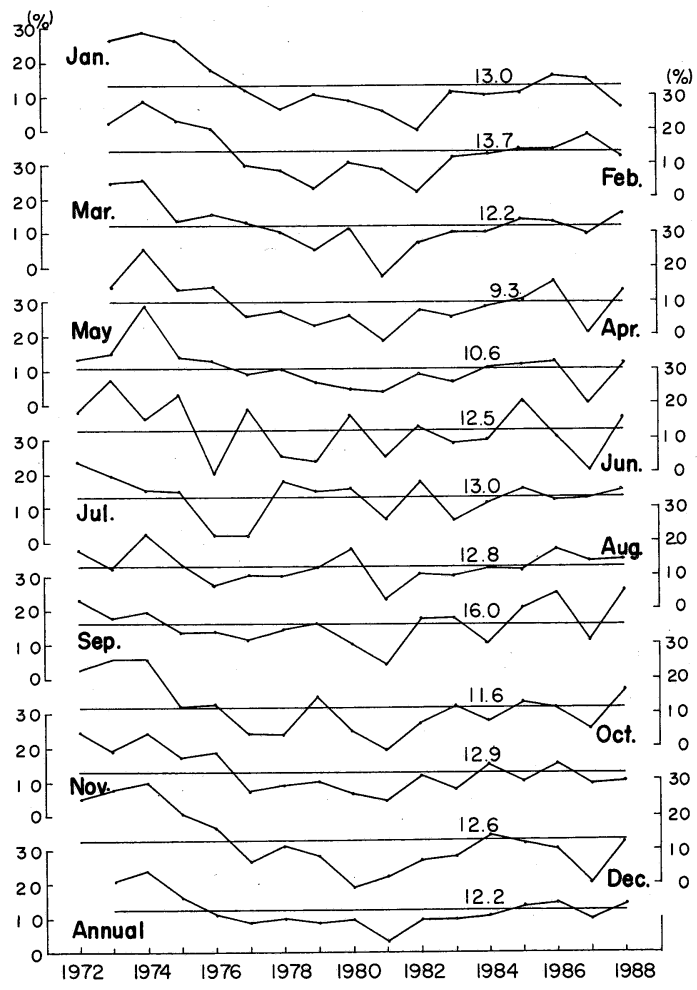

Figure 9. Annual variations of reduction index of solar radiation in Tokyo. 
tendency in the 1970's. In 1980's, an increasing tendency can be found compared with the late 1970's. On the annual basis, the reduction index is minimum in 1981, and afterwards, shows an increasing tendency and reaches $14 \%$ which is larger than the long-term mean value of $12.2 \%$.

Yearly variation is smaller in winter than in summer, because in Tokyo, the weather is more stable in winter than in summer. Monthly average values of reduction index show the lowest of 9.3\% in April, and the highest of $13.7 \%$ in February.

The recent reduction index is gradually increasing and approaching the atmospheric condition around the early 1970's again. As this is an important indicator of atmospheric pollution burden, it should be monitored continuously in the future.

\section{CONCLUDING REMARKS}

This paper describes the urban climate in Tokyo phenomenally from viewpoint of regional geography. Metropolitan Tokyo is still expanding to all directions today. In particular, water front exploitations are now advancing very dramatically including land reclamation along the beaches of Tokyo Bay. This in turn is likely to affect the sea breeze circulation. Consequently, the urban climate will be greatly influenced by this land modification.

Another important development affecting urban climate is the construction of high-rise buildings. At present, the typical area of high-rise buildings is Nishi-Shinjuku which is located just west of Shinjuku railway station. However, many high-rise buildings are under construction or planned for other areas.

The change of the earth's surface morphology leads to significant changes of albedo, sky view and roughness height. These kinds of modification of the earth's surface must cause significant changes to the climate in Tokyo in the future. Therefore it is inevitably necessary for urban climate to be constantly monitored from the climatological point of view.

\section{Acknowledgements}

I sincerely appreciate Dr. D. YAP, Ministry of the Environment, Ontario Government, Canada for detailed reviewing. Also I thank Prof. K. SEKINE, Gifu University for encouragements and drafting figures, and Prof. T. ICHIKAWA, Tokyo Gakugei University for the information of DID population. Also I am indebted to Mr. Y. SATO, graduate student and Miss S. ONO, student of Geography Department of Tokyo Gakugei University for drafting many figures.

(Received Oct. 31, 1989)

(Accepted Jan. 31, 1990)

\section{References}

HosAKI, S. (1975): Effects of a City on Precipitation Phenomena. Graduation Thesis of Tokyo Gakugei University, 50 p. (J)

KAWAMURA, T. (1985): Recent Change of Atmospheric Environment in Tokyo and Its Surrounding Area. Geographical Rev. Japan, (Ser. B) 58-1, 83-94. (E)

NishizAWA, T. et al. (1977): Distribution of Ground Temperature in the Central Area of Tokyo. Geographical Rev. Japan, 52-6, 283-292. (JE)

OKE, T.R. (1978): Boundary Layer Climate. Methuen \& Co. Ltd., New York, 372 p.

Омото, Y. (1988): City and Climate - Human Activities and Climatic Change, Kisho Kenkyu Note (Meteorological Research Note), No. 162, 213-231. (J)

YAmashita, S. (1973): Air Pollution Study from Measurements of Solar Radiation. Arch. Met. Geoph. Biokl., Ser. B, 21, 243-253.

YAMASHitA, S. (1988): Some Studies of Heat Island in Japan - With Special Emphasis on the Climatological Aspects. Geographical Rev. Japan, (Ser. B) 61-1, $1-13$. (E)

YONETANI, T. (1982): Increase in Number of Days with Heavy Precipitation in Tokyo Urban Area. J. Appl. Meteor., 21, 1466-1471.

Yoshino, M.M. (1975): Climate in a Small Area. Univ. of Tokyo Press, Tokyo, 549 p. (E)

Yoshino, M.M. (1977): Modification of Climate in Japan and the World. Kisho Kenkyu Note (Meterorological Research Note), No. 133, $1-25$. (J)

Yoshino, M.M. (1981): Change of Air Temperature Distribution Due to the Urbanization in Tokyo and Its Surrounding Regions. Sci. Rept. Inst. Geoscience, University of Tsukuba, Sect. A, 2, 45-60. (E) 


\section{東京の 都市気候}

山下 脩 二*

本報告は東京の都市気候について主として地誌的観点 から述べたものである。取り扱った気候要素は温度，降 水量, 湿度と日射量である。ただし，YoshINo（1981)， KaWAMURA (1985)，YAMASHita (1988) 飞部分的に 東京の都市気候や大気污染について発表されているの でここでは主としてこれら 3 論文で扱われていない現 象ないし観点から東京の都市気候を説明することを試み た。

気温は先ず観測開始以来からの経年変化を季節別に示 した。次に東京のヒートアイランド強度を時刻別・季節 別に示した。また，府中と越谷を東京の郊外地点の代表 として選び，東京との気温差からヒートアイランド強度 の頻度分布の日変化を求め, また，風向・風速による違
いを示した。 降水量については，観測開始以来の年降水量の経年変 化を求め,さらに降水日数の階級別頻度分布を示した。 階級区分は，0.0mm, 0.1-1.0mm, 1.1-9.9mm. 10.0 $\mathrm{mm}$ 以上である。また， $31 \mathrm{~mm}$ 以上の対流性の雨の日数 の都心と郊外の比較から, 都市の影響が単純ではないこ とを示した。

湿度については近年急速に減少していることを示し た。また，日射量については，1972年以来の減少示数の 季節別経年变化を示し，トータルでみた場合の都市大気 質の変化は必ずしも改善されているわけではないことを 明らかにした。 